\title{
CALCIUM, MAGNESIUM AND POTASSIUM IN CLAY, SILT AND FINE SAND FRACTIONS OF SOME FINNISH SOILS
}

\author{
Armi Kaila and Ritva Ryti \\ University of Helsinki, Department of Agricultural Chemistry
}

Received April 28, 1967

The mineralogical composition of the mechanical fractions in soils is likely to be more or less different because of the differences in the resistance of various minerals against weathering. Thus, the chemical composition of the finer material will not be quite similar to that of the coarser particles. In general, the content of silicon is found to decrease and that of aluminium and iron increase with a decrease in the size of particles. Several investigators report that the contents of calcium, magnesium and potassium are higher in the finer fractions than in the coarser material, but contrary results are also recorded (PUCHNER 1907, HALL and Russell 1911, Hendrick and Ogg 1916, Brown and Byers 1932).

Only a few published data are available of the chemical composition of mechanical fractions in Finnish mineral soils. According to analyses of two clay soils (SALMINEN 1935), material less than $2 \mu$, had a lower content of silicon and calcium, and a higher content of aluminium, iron and magnesium than the original soil. In one soil the potassium content of the clay fraction was higher, in the other soil lower than that of the original sample. In nineteen soil samples analysed by KERÄNEN (1946), the content of nonexchangeable potassium in the clay fraction was in one case equal to, in ten cases lower, and in eight cases higher than the total content in the original sand, morene, mud and clay soils.

As a contribution to this subject the present paper reports results on the calcium, magnesium and potassium content of clay, silt and fine sand fractions of soil samples collected from three layers of ten clay, silt, or fine sand soils. In addition to the total contents of these nutrients, a nonexchangeable fraction released by an acid treatment is determined. Attention is also paid to the amounts of readily exchangeable calcium, magnesium and potassium in these particle size fractions.

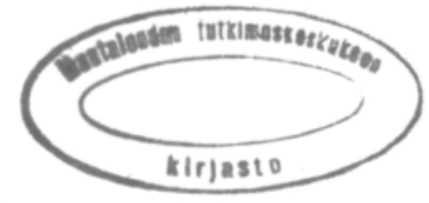




\section{Material and methods}

The soil samples listed in Table 1 were collected from various parts of Finland. Samples Vi $1-3$ are from the southern coast, Le 1 and Sa 1 from southern and samples HP $1-4$ from central parts of

Table 1. Soil samples

\begin{tabular}{|c|c|c|c|c|c|c|c|c|c|c|}
\hline & & \multirow{3}{*}{$\begin{array}{l}\text { Depth } \\
\mathrm{cm}\end{array}$} & \multirow{3}{*}{$\mathrm{pH}$} & \multirow{3}{*}{$\begin{array}{c}\text { Org. C } \\
\%\end{array}$} & \multirow{2}{*}{\multicolumn{3}{|c|}{$\begin{array}{c}\text { Particle size fractions } \\
\%\end{array}$}} & \multicolumn{3}{|c|}{ Total content of } \\
\hline & & & & & & & & \multirow{2}{*}{$\begin{array}{c}\mathrm{Ca} \\
\%\end{array}$} & \multirow{2}{*}{$\begin{array}{c}\mathrm{Mg} \\
\%\end{array}$} & \multirow{2}{*}{$\begin{array}{l}\mathrm{K} \\
\%\end{array}$} \\
\hline & & & & & $<2 \mu$ & $2-20$ & $-200 \mu$ & & & \\
\hline \multirow[t]{3}{*}{ Vi } & 1 a & $0-20$ & 3.5 & 2.9 & 46 & 35 & 18 & 1.03 & 1.19 & 2.62 \\
\hline & b & $20-40$ & 3.6 & 2.9 & 42 & 35 & 21 & 1.04 & 1.16 & 2.54 \\
\hline & c & $40-65$ & 3.3 & 2.2 & 51 & 33 & 14 & 0.98 & 1.28 & 2.68 \\
\hline \multirow[t]{3}{*}{ Vi } & $2 \mathrm{a}$ & $0-20$ & 4.8 & 1.0 & 45 & 18 & 25 & 1.17 & 1.37 & 2.81 \\
\hline & b & $20-40$ & 5.2 & 0.5 & 74 & 12 & 11 & 1.19 & 2.01 & 3.27 \\
\hline & c & $40-65$ & 5.8 & 0.4 & 89 & 9 & 2 & 1.17 & 2.48 & 3.41 \\
\hline \multirow[t]{3}{*}{ Vi } & 3 a & $0-20$ & 4.4 & 4.6 & 47 & 31 & 17 & 0.95 & 0.96 & 2.27 \\
\hline & b & $20-40$ & 3.7 & 2.1 & 54 & 24 & 21 & 0.81 & 1.08 & 2.68 \\
\hline & c & $50-70$ & 3.6 & 1.6 & 72 & 21 & 6 & 0.69 & 1.41 & 3.06 \\
\hline \multirow[t]{3}{*}{ Le } & $1 \mathrm{a}$ & $0-20$ & 5.3 & 5.5 & 32 & 29 & 34 & 1.29 & 1.03 & 2.12 \\
\hline & b & $45-60$ & 5.7 & 0.6 & 70 & 17 & 12 & 1.12 & 1.91 & 3.08 \\
\hline & $\mathrm{c}$ & $95-105$ & 6.3 & 0.3 & 40 & 54 & 5 & 1.51 & 1.86 & 3.13 \\
\hline \multirow[t]{3}{*}{ HP } & $1 \mathrm{a}$ & $0-20$ & 6.1 & 2.5 & 18 & 68 & 11 & 1.73 & 0.91 & 2.61 \\
\hline & b & $30-40$ & 5.8 & 1.1 & 18 & 80 & 1 & 1.69 & 0.98 & 2.78 \\
\hline & c & $50-60$ & 6.0 & 0.1 & 14 & 66 & 19 & 1.82 & 0.92 & 2.78 \\
\hline \multirow[t]{3}{*}{ HP } & 2 a & $0-20$ & 5.8 & 2.2 & 16 & 68 & 15 & 1.66 & 0.89 & 2.56 \\
\hline & b & $30-40$ & 6.0 & 0.5 & 8 & 74 & 17 & 1.88 & 0.95 & 2.77 \\
\hline & c & $50-60$ & 6.2 & 0.6 & 17 & 78 & 5 & 1.80 & 1.06 & 2.80 \\
\hline \multirow[t]{3}{*}{ HP } & 3 a & $0-20$ & 5.1 & 2.3 & 30 & 39 & 29 & 1.38 & 0.86 & 2.54 \\
\hline & b & $30-40$ & 4.9 & 1.3 & 28 & 48 & 22 & 1.40 & 0.99 & 2.68 \\
\hline & c & $50-60$ & 5.0 & 0.2 & 36 & 58 & 4 & 1.61 & 1.56 & 3.08 \\
\hline \multirow[t]{3}{*}{$\mathrm{HP}$} & 4 a & $0-20$ & 4.9 & 3.0 & 30 & 56 & 13 & 1.51 & 1.09 & 2.68 \\
\hline & b & $45-60$ & 5.9 & 0.2 & 36 & 53 & 11 & 1.76 & 1.34 & 2.98 \\
\hline & c & $95-105$ & 6.0 & 0.3 & 38 & 56 & 6 & 1.76 & 1.56 & 3.14 \\
\hline \multirow[t]{3}{*}{ To } & $1 \mathrm{a}$ & $5-15$ & 4.7 & 1.4 & 11 & 61 & 27 & 1.25 & 1.17 & 1.99 \\
\hline & b & $20-30$ & 6.2 & 0.5 & 40 & 57 & 3 & 1.76 & 1.84 & 2.86 \\
\hline & c & $40-50$ & 6.4 & 0.4 & 18 & 72 & 10 & 1.63 & 1.65 & 2.60 \\
\hline \multirow[t]{3}{*}{$\mathrm{Sa}$} & $1 \mathrm{a}$ & $10-20$ & 5.2 & 0.6 & 24 & 36 & 35 & 1.13 & 0.92 & 2.51 \\
\hline & b & $30-40$ & 5.8 & 0.2 & 18 & 30 & 51 & 1.50 & 0.95 & 2.41 \\
\hline & c & $90-100$ & 6.3 & 0.2 & 83 & 11 & 6 & - & - & 3.17 \\
\hline
\end{tabular}


the country. Soil To 1 represents eastern Finland. The samples were taken from cultivated lands, except the samples Vi 2, To 1 and Sa 1 which were virgin soils; the sample Vi 1 was from the edge of a ditch.

Soil $\mathrm{pH}$ was measured in $0.01 \mathrm{M} \mathrm{CaCl}_{2}$ in the ratio of soil to solution of $1: 2.5$. Organic carbon was determined by wet combustion. The mechanical composition was estimated by the common hydrometer method after the destruction of organic matter with hydrogen peroxide.

Organic matter was not destroyed when the fractions, $<2 \mu, 2-20 \mu$, and $20-200 \mu$, were separated. The soil samples were dispersed in distilled water by sonic vibration and the separation was performed according to a procedure developed at this institute by Mr. Paavo Elonen, M. Sci. The sand fraction was eliminated by sieving from the dispersed sample. The other fractions were separated by repeated sedimentation in water and decantation. The excess water was evaporated from the clay suspension on a water bath, and the material was dried at room temperature. The silt suspension and the fine sand suspension were centrifuged for the elimination of water and dried at room temperature.

Sodium carbonate fusing was used for the determination of the total contents of calcium, magnesium and potassium both in the original soil samples and in the fractions.

Readily exchangeable calcium, magnesium and potassium were estimated by extraction for one hour with $0.5 \mathrm{~N}$ neutral ammonium acetate in the ratio of 1 to 10 . The release of nonexchangeable forms were estimated by treating with $1 \mathrm{~N} \mathrm{HCl}$ for 18 hours the samples extracted with ammonium acetate for the removal of readily exchangeable cations. The samples were not dried before the acid was added, and it was found by weighing that the ammonium acetate solution left in the samples diluted the acid from $1.0 \mathrm{~N}$ to $0.8 \mathrm{~N}$ in the samples of clay fraction, and to 0.9 in the other samples, and correspondingly decreased the ratio of extraction, 1 to 10 .

Calcium and magnesium in the extracts were determined with a Perkin Elmer atomic absorption spectrophotometer 290, and potassium with an EEL flame photometer.

\section{Results}

The total content of calcium in the original soil samples (Table 1) ranges from 0.69 to 1.88 per cent, that of magnesium from 0.86 to 2.48 per cent, and that of potassium from 1.99 to 3.41 per cent. The mean values with the confidence limits at the 95 per cent level are the following:

$$
1.39 \pm 0.13 \% \mathrm{Ca} \quad 1.33 \pm 0.17 \% \mathrm{Mg} \quad 2.75 \pm 0.12 \% \mathrm{~K}
$$

Thus, the average content of potassium in these soils appears to be about twice as high as that of calcium or magnesium.

The results in Table 2 show characteristic differences in the distribution of these nutrients between the various particle size fractions. In almost all soils the calcium content is lowest in the clay material, and in the silt material of about the same order as in the fine sand. The magnesium content, again, is in all samples lowest in the fine sand and highest in the clay fraction. The potassium content also seems to be highest in the clay fraction and lowest in the fine sand fraction, but, in several samples, differences between the silt and clay materials are not marked.

The variation in the total contents of calcium, magnesium and potassium in these three mechanical fractions is relatively large, as shown by the following ranges: 
Table 2. Total content of $\mathrm{Ca}, \mathrm{Mg}$ and $\mathrm{K}$ in clay, silt and fine sand fractions

\begin{tabular}{|c|c|c|c|c|c|c|c|c|c|c|}
\hline & & \multicolumn{3}{|c|}{ Tot. Ca \% } & \multicolumn{3}{|c|}{ Tot. Mg \% } & \multicolumn{3}{|c|}{ Tot. K \% } \\
\hline & & $<2 \mu$ & $2-20 \mu$ & $20-200 \mu$ & $<2 \mu$ & $2-20 \mu$ & $20-200 \mu$ & $<2 \mu$ & $2-20 \mu$ & $20-200 \mu$ \\
\hline \multirow[t]{3}{*}{ Vi 1} & $\mathbf{a}$ & 0.60 & 1.26 & 1.47 & 1.84 & 1.00 & 0.49 & 3.07 & 2.47 & 1.97 \\
\hline & b & 0.61 & 1.13 & 1.44 & 1.80 & 1.02 & 0.53 & 3.02 & 2.37 & 2.02 \\
\hline & c & 0.63 & 1.17 & 1.40 & 1.79 & 1.11 & 0.60 & 3.12 & 2.62 & 2.02 \\
\hline \multirow[t]{3}{*}{ Vi 2} & $\mathbf{a}$ & 0.95 & 1.36 & 1.55 & 2.23 & 1.15 & 0.47 & 3.25 & 2.68 & 1.97 \\
\hline & b & 1.04 & 1.26 & 1.61 & 2.40 & 1.34 & 0.58 & 3.47 & 2.96 & 1.99 \\
\hline & c & 1.19 & 1.44 & 1.51 & 2.53 & 1.55 & 0.53 & 3.54 & 3.19 & 2.10 \\
\hline \multirow[t]{3}{*}{ Vi 3} & $\mathbf{a}$ & 0.73 & 1.22 & 1.29 & 1.30 & 0.84 & 0.54 & 2.63 & 2.19 & 1.79 \\
\hline & b & 0.46 & 1.08 & 1.36 & 1.45 & 0.99 & 0.54 & 3.07 & 2.74 & 2.03 \\
\hline & c & 0.52 & 0.94 & 0.99 & 1.61 & 1.17 & 0.90 & 2.87 & 2.52 & 1.92 \\
\hline \multirow[t]{3}{*}{ Le 1} & $\mathbf{a}$ & 1.15 & 1.44 & 1.50 & 1.94 & 0.96 & 0.42 & 2.67 & 2.32 & 1.77 \\
\hline & b & 0.95 & 1.32 & 1.36 & 2.19 & 1.38 & 0.73 & 3.37 & 3.17 & 1.79 \\
\hline & c & 1.31 & 1.61 & 1.78 & 2.35 & 1.63 & 0.92 & 3.27 & 3.27 & 2.17 \\
\hline \multirow[t]{3}{*}{ HP 1} & $\mathbf{a}$ & 1.39 & 1.70 & - & 1.68 & 0.80 & - & 2.57 & 2.57 & - \\
\hline & b & 1.24 & 1.78 & 1.88 & 1.81 & 0.90 & 0.48 & 2.77 & 2.87 & 2.67 \\
\hline & c & 1.32 & 1.88 & 2.01 & 1.99 & 0.84 & 0.49 & 2.87 & 2.77 & 2.57 \\
\hline \multirow[t]{3}{*}{ HP : } & $\mathbf{a}$ & 1.41 & 1.72 & 1.83 & 1.59 & 0.83 & 0.45 & 2.62 & 2.72 & 2.52 \\
\hline & b & - & 1.90 & 1.90 & - & 0.88 & 0.49 & - & 2.87 & 2.67 \\
\hline & c & 1.33 & 1.88 & 2.01 & 2.01 & 0.88 & 0.54 & 2.87 & 2.87 & 2.67 \\
\hline \multirow[t]{3}{*}{ HP : } & $a$ & 1.10 & 1.54 & 1.69 & 1.53 & 0.78 & 0.41 & 2.73 & 2.67 & 2.52 \\
\hline & b & 0.99 & 1.59 & 1.33 & 1.62 & 0.89 & 0.30 & 2.83 & 2.79 & 2.01 \\
\hline & c & 1.34 & 1.71 & 1.88 & 2.11 & 1.26 & 0.55 & 3.12 & 3.02 & 2.61 \\
\hline \multirow[t]{3}{*}{$\mathrm{HP}$} & $a$ & 1.36 & 1.55 & 1.76 & 1.90 & 0.88 & 0.41 & 2.92 & 2.67 & 2.32 \\
\hline & b & 1.57 & 1.86 & 1.81 & 2.16 & 1.07 & 0.43 & 3.30 & 2.97 & 2.42 \\
\hline & c & 1.49 & 1.88 & 1.92 & 2.37 & 1.21 & 0.57 & 3.41 & 3.08 & 2.52 \\
\hline \multirow[t]{3}{*}{ To 1} & $\mathrm{a}$ & 1.05 & 1.41 & 1.45 & 2.18 & 1.45 & 0.60 & 2.67 & 2.42 & 1.47 \\
\hline & b & 1.69 & 1.82 & 1.61 & 2.72 & 1.55 & 0.70 & 3.47 & 2.72 & 1.67 \\
\hline & c & 1.53 & 1.64 & - & 2.58 & 1.57 & - & 3.22 & 2.67 & - \\
\hline \multirow[t]{3}{*}{ Sa 1} & $\mathbf{a}$ & 0.60 & 1.48 & 1.42 & 1.95 & 0.76 & 0.34 & 2.87 & 2.62 & 2.15 \\
\hline & b & 0.89 & 1.80 & 1.70 & 2.23 & 0.98 & 0.43 & 2.87 & 2.62 & 2.15 \\
\hline & c & 1.10 & 1.51 & 1.53 & 2.37 & 1.45 & 0.63 & 3.25 & 3.19 & 2.10 \\
\hline
\end{tabular}

Tot. Ca \%

$<2 \mu$
$2-20 \mu$
$20-200 \mu$

$0.46-1.69$

$0.94-1.90$

$0.99-2.01$
Tot. $\mathrm{Mg} \%$

$1.30-2.72$

$0.76-1.63$

$0.30-0.92$
Tot. K \%

$2.57-3.54$

$2.19-3.27$

$1.47-2.67$ 
In the clay fraction, the relatively largest variation appears to be in the content of calcium, and lowest in that of potassium. The magnesium content varies most in the fine sand fraction.

In the 29 samples of clay, 30 samples of silt and 28 samples of fine sand the calcium, magnesium and potassium contents are characterized by the following mean values (with the confidence limits at the 95 per cent level):

$\begin{array}{rccc} & \text { Tot. Ca } \% & \text { Tot. } \mathrm{Mg} \% & \text { Tot. K } \% \\ <2 \mu & 1.09 \pm 0.13 & 2.01 \pm 0.14 & 3.02 \pm 0.11 \\ 2-20 \mu & 1.53 \pm 0.10 & 1.10 \pm 0.10 & 2.75 \pm 0.10 \\ 20-200 \mu & 1.61 \pm 0.10 & 0.54 \pm 0.65 & 2.16 \pm 0.13\end{array}$

On the average, the total calcium content in the clay fraction preparates is about two thirds of that in the silt and fine sand fractions. The mean content of total magnesium is in the clay fraction almost twice as high as in the silt fraction and about four times as high as in the fine sand material. The average potassium content of the clay fraction is statistically significantly higher than that of the silt material, although the difference is rather low. In the fine sand fraction the potassium content is averagely about two thirds of that in the clay fraction.

According to these mean contents, there seems to be in the clay fraction about twice as much magnesium, and three times as much potassium as there is calcium. In the fine sand fraction, the magnesium content appears to be by far the lowest, corresponding to only one third of the calcium content and to one fourth of the potassium content. In the silt fraction, also, the mean content of magnesium is lower than that of calcium and less than one half of that of potassium.

These average amounts of calcium, magnesium and potassium expressed as equivalents per $100 \mathrm{~g}$ of the clay, silt and fine sand preparates are the following:

$\begin{array}{rrrr} & \text { Ca me/100 g } & \text { Mg me/100 g } & \text { K me/100 g } \\ <2 \mu & 54.5 \pm 6.5 & 167.5 \pm 11.7 & 77.4 \pm 2.8 \\ 2-20 \mu & 76.5 \pm 5.0 & 91.7 \pm 8.3 & 70.5 \pm 2.6 \\ 20-200 \mu & 80.5 \pm 5.0 & 45.0 \pm 5.0 & 55.4 \pm 3.3\end{array}$

Thus, there seems to be in the clay fraction, on the average, about three times as much magnesium as calcium, and almost $11 / 2$ times as much potassium as calcium. In the silt fraction, these mean contents are more of the same order, and in the fine sand fraction the magnesium and potassium contents are about two thirds of that of calcium.

Samples with a relatively high content of calcium in one of the fractions, usually also have a high content of calcium in the other fractions. This seems to hold in regard to the magnesium content, but less distinctly in regard to the potassium content. The total linear correlation coefficients between the respective contents of these nutrients in the clay and silt fractions on the one hand, and in the silt and fine sand fractions on the other hand, are the following: 
between

clay and silt fractions

silt and fine sand fractions

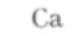

$0.84 * * *$

$0.86 * * *$
$\mathrm{Mg}$

$0.79 * * *$

$0.70 * * *$
K

$0.66 * * *$

$0.40^{*}$

The variation in the calcium content does not seem to depend on the variation in the magnesium content: only in the clay fraction a low positive correlation with $\mathrm{r}=0.52^{* *}$ may be found. The magnesium content is in the clay fraction more closely correlated with the potassium content, $r=0.75^{* * *}$, but in the silt fraction the relationship is not close, $\mathrm{r}=0.48^{* *}$. The contents of calcium and potassium, on the other hand, are correlated in the fine sand fraction: $r=0.78^{* * *}$, but not in the finer materials.

The total content of calcium both in the original soils and in the particle size fractions appears to be of the same order in the surface samples and in the samples of deeper layers. The contents of magnesium and potassium, again, tend to be lower in the topsoil than in the deeper layers.

Treatment of the samples with $\mathrm{HCl}$ at $50^{\circ} \mathrm{C}$, after removal of the readily exchangeable cations, dissolved from the different fractions calcium, magnesium and potassium according to the data in Table 3. From the clay material, and in most cases also from the silt fraction, markedly lower amounts of calcium as compared with those of magnesium were dissolved. The content of nonexchangeable acid-soluble potassium in the clay and silt fractions is also considerably lower than that of magnesium, except in the samples Vi 1 and Vi $2 \mathrm{a}-\mathrm{b}$ which are particularly rich in this kind of potassium and poor in this kind of magnesium. Only in two samples of the clay fraction and in about one third of the silt samples, the amount of calcium dissolved appears to be higher than that of potassium. In the fine sand fraction, on the other hand, usually less magnesium and potassium has been extracted than calcium.

The average amounts of nonexchangeable acid-soluble calcium, magnesium and potassium in the 29 samples of clay, 28 samples of silt, and 19 samples of fine sand analyzed are the following:

$\begin{array}{rrrr} & \text { Ca mg/100 } & \text { Mg mg/100 g } & \mathrm{K} \mathrm{mg} / 100 \mathrm{~g} \\ <2 \mu & 160 \pm 30 & 680 \pm 110 & 400 \pm 70 \\ 2-20 \mu & 130 \pm 30 & 350 \pm 70 & 230 \pm 50 \\ 20-200 \mu & 120 \pm 30 & 90 \pm 30 & 60 \pm 20\end{array}$

Thus there seems to be magnesium in the clay fraction, on the average, about four times as much as calcium and more than $11 / 2$ times as much as potassium. Calculated on the equivalent basis, the amount of nonexchangeable magnesium dissolved by acid from the clay material will be about seven times that of calcium and more than five times that of potassium. Expressed in this way, the mean content of magnesium in the silt traction is four to five times higher than those of calcium and potassium.

Even if a comparison between the different fractions is not quite reliable on the basis of these figures, it may be noted that the average amounts of nonexchange- 
Table 3. Nonexchangeable acid-soluble $\mathrm{Ca}, \mathrm{Mg}$ and $\mathrm{K}$ in clay, silt and fine sand fractions (expressed as $\mathrm{mg} / 100 \mathrm{~g}$ )

\begin{tabular}{|c|c|c|c|c|c|c|c|c|c|c|}
\hline \multirow{3}{*}{$\begin{array}{l} \\
\mathrm{Vi}\end{array}$} & \multirow{5}{*}{$\begin{array}{l}1 \mathrm{a} \\
\mathrm{b} \\
\mathrm{c}\end{array}$} & \multicolumn{3}{|c|}{$\mathrm{Ca}$} & \multicolumn{3}{|c|}{$\mathrm{Mg}$} & \multicolumn{3}{|c|}{$\mathbf{K}$} \\
\hline & & \multirow{2}{*}{$\frac{<2 \mu}{70}$} & \multicolumn{2}{|c|}{$2-20 \mu 20-200 \mu$} & \multirow{2}{*}{$\frac{<2 \mu}{170}$} & \multirow{2}{*}{$\begin{array}{c}2-20 \mu \\
90\end{array}$} & \multirow{2}{*}{$\begin{array}{c}20-200 \mu \\
30\end{array}$} & \multirow{2}{*}{$\frac{<2 \mu}{710}$} & \multicolumn{2}{|c|}{$2-20 \mu 20-200 \mu$} \\
\hline & & & 90 & 100 & & & & & 310 & 90 \\
\hline & & 60 & 70 & 70 & 180 & 90 & 30 & 630 & 290 & 100 \\
\hline & & 60 & 80 & 80 & 180 & 110 & 40 & 750 & 430 & 150 \\
\hline \multirow[t]{3}{*}{ Vi } & 2 a & 120 & 120 & 100 & 200 & 110 & 30 & 540 & 330 & 50 \\
\hline & $\mathrm{b}$ & 140 & 120 & - & 220 & 140 & - & 630 & 440 & - \\
\hline & c & 200 & - & - & 1240 & - & - & 710 & - & - \\
\hline \multirow[t]{3}{*}{ Vi } & 3 a & 130 & 100 & 90 & 470 & 300 & 160 & 320 & 200 & 100 \\
\hline & b & 30 & 20 & 20 & 640 & 460 & 170 & 470 & 350 & 120 \\
\hline & c & 30 & 30 & - & 740 & 550 & - & 530 & 390 & - \\
\hline \multirow[t]{3}{*}{ Le } & $1 \mathrm{a}$ & 250 & 320 & 90 & 670 & 390 & 110 & 320 & 180 & 50 \\
\hline & b & 140 & 130 & - & 850 & 550 & - & 370 & 300 & - \\
\hline & c & 210 & 190 & - & 800 & 690 & - & 330 & 350 & - \\
\hline \multirow[t]{3}{*}{ HP } & $1 \mathrm{a}$ & 270 & 160 & 190 & 690 & 270 & 80 & 210 & 100 & 40 \\
\hline & b & 150 & 120 & 150 & 690 & 250 & 70 & 240 & 90 & 40 \\
\hline & c & 160 & 170 & 210 & 700 & 220 & 60 & 280 & 120 & 40 \\
\hline \multirow[t]{3}{*}{ HP } & $2 \mathrm{a}$ & 320 & 170 & 220 & 650 & 270 & 90 & 200 & 100 & 40 \\
\hline & b & 190 & 170 & 180 & 720 & 290 & 80 & 220 & 120 & 50 \\
\hline & c & 180 & 190 & - & 770 & 270 & - & 270 & 120 & - \\
\hline \multirow[t]{3}{*}{$\mathrm{HP}$} & 3 a & 160 & 110 & 110 & 580 & 320 & 50 & 160 & 90 & 30 \\
\hline & b & 110 & 90 & 110 & 510 & 290 & 60 & 140 & 100 & 30 \\
\hline & c & 170 & 160 & - & 810 & 460 & - & 290 & 240 & - \\
\hline \multirow[t]{3}{*}{ HP } & $4 \mathrm{a}$ & 180 & 150 & 140 & 830 & 370 & 70 & 260 & 120 & 30 \\
\hline & b & 190 & 180 & 160 & 860 & 350 & 70 & 340 & 200 & 40 \\
\hline & c & 210 & 200 & - & 920 & 430 & - & 470 & 260 & - \\
\hline \multirow[t]{3}{*}{ To } & $1 \mathrm{a}$ & - & 90 & - & - & 680 & - & - & 320 & - \\
\hline & b & 230 & 160 & - & 1110 & 520 & - & 750 & 360 & - \\
\hline & c & 170 & 130 & 110 & 910 & 560 & 280 & 550 & 370 & 170 \\
\hline \multirow[t]{3}{*}{$\mathrm{Sa}$} & $1 \mathrm{a}$ & 110 & 60 & 50 & 800 & 380 & 70 & 260 & 130 & 20 \\
\hline & b & 200 & 190 & 140 & 890 & 440 & 110 & 280 & 100 & 30 \\
\hline & c & 220 & - & - & 1040 & - & - & 420 & - & - \\
\hline
\end{tabular}

able calcium dissolved from clay, silt and fine sand are of the same order, but that about four times as much potassium and magnesium has been dissolved from the silt than the fine sand fraction, and almost twice as much from the clay than the silt fraction. 
The part of total calcium dissolved by the acid treatment corresponds to 6 to 23 per cent in the clay fraction, 2 to 12 per cent in the silt fraction, and 1 to 12 per cent in the fine sand fraction. The corresponding ranges for magnesium are 9 to 49 per cent in the clay fraction, 9 to 50 per cent in the silt fraction, and 5 to 31 per cent in the fine sand fraction. The part of potassium dissolved seems tc be of the same order as that of calcium, or 5 to 24 per cent of the total content in the clay fraction, 3 to 10 per cent in the silt fraction, and 1 to 7 per cent in the fine sand material. The mean values are the following:

\begin{tabular}{rrrr} 
& \multicolumn{3}{c}{ Per cent of total } \\
& Ca & Mg & K \\
$<2 \mu$ & $14 \pm 2$ & $34 \pm 5$ & $13 \pm 2$ \\
$2-20 \mu$ & $9 \pm 1$ & $33 \pm 5$ & $9 \pm 2$ \\
$20-200 \mu$ & $7 \pm 1$ & $17 \pm 4$ & $3 \pm 1$
\end{tabular}

These figures show that in all fractions the nonexchangeable magnesium is more readily dissolved by acid than calcium and potassium. It is of interest to note that this kind of magnesium corresponds, both in the clay fraction and in the silt fraction to about one third of the total magnesium content.

There seems to be no close relationship between the contents of nonexchangeable acid soluble calcium, magnesium and potassium with each other. only in the clay fraction a low positive correlation may be found between the contents of calcium and magnesium, $\mathrm{r}=0.53^{* *}$. On the other hand, the contents of the respective nutrients tend to vary in the same way in these different particle size fractions The correlation coefficients for the contents of calcium, magnesium and potassium are the following:

between
clay and silt fractions
silt and fine sand fractions

$\begin{array}{ccc}\mathrm{Ca} & \mathrm{Mg} & \mathrm{K} \\ 0.81^{* * *} & 0.81^{* * *} & 0.87^{* * *} \\ 0.53^{* *} & 0.78^{* * *} & 0.86^{* * *}\end{array}$

The correlation between the nonexchangeable acid-soluble potassium in the clay and silt fractions, and particularly that in the silt and fine sand fractions, appear to be markedly closer than the corresponding relationship between the total contents of potassium in these fractions. The correlation found between the nonexchangeable magnesium in these fractions seems to be as close as that of the total amounts, but the relationship is poor between the nonexchangeable calcium contents in the silt and fine sand fractions, contrary to that between the total amounts.

The quantities of readily exchangeable calcium in the clay fraction is in most soils higher than, or at least equal to that part which may be extracted by the successive acid treatment. In the coarser material, especially in fine sand, the contents of the latter kind of calcium are usually markedly higher than the readily exchangeable form. In all particle size fractions the contents of readily exchangeable magnesium and, particularly, of potassium are considerably lower than the corresponding amounts of nonexchangeable acid-soluble forms. 
The treatment with ammonium acetate extracted from 22 samples 31 to 522 $\mathrm{mg} \mathrm{Ca}, 7$ to $250 \mathrm{mg} \mathrm{Mg}$, and 9 to $94 \mathrm{mg} \mathrm{K}$ per $100 \mathrm{~g}$ of clay, from 21 samples 11 to $94 \mathrm{mg} \mathrm{Ca}, 4$ to $56 \mathrm{mg} \mathrm{Mg}$, and 3 to $10 \mathrm{mg} \mathrm{K}$ per $100 \mathrm{~g}$ of silt, and from 14 samples 9 to $94 \mathrm{mg} \mathrm{Ca}, 2$ to $23 \mathrm{mg} \mathrm{Mg}$ and 1 to $9 \mathrm{mg} \mathrm{K}$ per $100 \mathrm{~g}$ of fine sand. In some of the cultivated soils, the contents of all these cations are highest in the samples of the plough layer, but there are also soils in which the deeper layers are richest even in exchangeable calcium. These results correspond to the following mean values:

$\begin{array}{rrrr} & \mathrm{Ca} \mathrm{mg} / 100 \mathrm{~g} & \mathrm{Mg} \mathrm{mg} / 100 \mathrm{~g} & \mathrm{~K} \mathrm{mg} / 100 \mathrm{~g} \\ <2 \mu & & & \\ 2-20 \mu & 71 \pm 51 & \pm 28 & 29 \pm 8 \\ 20-200 \mu & 41 \pm 17 & 5 \pm 1 & 5 \pm 2 \\ & & 16 & 2 \pm 1\end{array}$

As could be expected, the readily exchangeable cations are highest in the clay fraction. According to these mean contents, there is in this fraction about fourteen times as much magnesium and potassium as in the fine sand fraction, yet, only somewhat less than six times as much calcium as in fine sand, and about three times as much as in silt. The clay fraction contains more than four times as much readily exchangeable magnesium and almost six times as much potassium as the silt material.

The content of readily exchangeable calcium corresponds to 6 to 59 per cent, on an average, to about 20 per cent of that of the total calcium in the clay fraction. This is more than the part represented by nonexchangeable acid-soluble calcium. In the silt fraction the part of readily exchangeable calcium is from 1 to 19 , on the average, about 5 per cent of the total content. The readily exchangeable magnesium content appears to be in the clay fraction from less than 1 to 11 per cent, or averagely about 3 per cent of the total content of magnesium, and thus only about one tenth of the corresponding amount of nonexchangeable magnesium released by acid.

When the average amounts of readily exchangeable cations are expressed as $\mathrm{me} / 100 \mathrm{~g}$ of sample, there will be in the clay fraction $11.4 \pm 2.5 \mathrm{me} \mathrm{Ca}$, and $5.8 \pm$ $2.3 \mathrm{me} \mathrm{Mg}$, and the ratio of $\mathrm{Ca}: \mathrm{Mg}$ will be about 2 to 1 . In the silt fraction the corresponding ratio will be 3 to 1 , and in the fine sand material about 5 to 1 . The ratio of readily exchangeable magnesium to potassium will be $8-10$ to 1 in all fractions. The material is far too scanty to allow any drawing of reliable conclusions on the possible differences in the composition of the exchangeable cations in the different particle size fractions.

\section{Discussion}

The separation of the clay, silt and fine sand fractions was performed without any drastic treatments, but it is impossible to prevent all changes in the material. The loss of water soluble cations is of no significant importance in these soils, but it is likely that the exchangeability of the cations, particularly that of potassium in the particle size separates, will not be equal to that under the original conditions. 
It is also likely that organic matter will accumulate in the material less than $2 \mu$. The only criterion the present data offer for the estimation of the reliability of the results is the degree of agreement between the values determined of the original soil samples and those calculated on the basis of the mechanical composition of the sample and the respective contents of the nutrients in the particle size fractions. It was found that the total contents of calcium, magnesium, and potassium estimated in these two ways agreed well with each other. There was also a surprisingly good accordance between the respective values of nonexchangeable acid-soluble calcium and magnesium.

In all the samples studied, the total content of calcium was lower in the clay fraction than in the coarser material. This is in accordance only with the results on a Scottish Glacial soil reported by Hendrick and OGG (1916). In the three English soils analysed by Hall and Russell (1911), and in ten American soils analysed by Brown and BYERs (1932), as well as in the average values calculated by HENDRICK and OGG (1916) on the basis of the results obtained by FAILYER, SMITH and WADE in 1908 for ten Glacial soils, three residual soils and seven Coastal plain soils, the content of calcium is highest in the clay fraction, or in the finer silt material. This difference may be attributed to differences in the mineralogical composition and in the stage of weathering of the mineral material in Finland and in these other parts of the world. In Finnish soils calcium is known to occur mainly as plagioclases the anorthite content of which will be the lower the finer the material is. The low state of weathering of our soils explains the relatively high content of calcium in the coarser particles.

The part of calcium in the mineral lattice of the clay material seems to be markedly lower than that of magnesium and particularly that of potassium. On the average, about one fifth of calcium in the clay fraction was readily exchangeable, and it is likely that a more thorough extraction would have given even higher results. A large proportion of these calcium ions may be adsorbed by organic matter which tended to be accumulated in the finest fraction. The readily exchangeable and nonexchangeable acid-soluble calcium represented in the present material about one third of the total calcium content in the clay fraction.

Magnesium appears to be at its highest in the clay fraction. Biotite, amphiboles and pyroxenes which are the main magnesium containing primary minerals in our soils are relatively readily weathered and do not tend to remain as coarser particles. The clay and silt fractions of our soils are known to be composed largely of micaceous minerals, vermiculite and chlorite (SOVERI 1956, SoverI and HYYPPÄ 1966).

Potassium occurs in our rocks both in readily weatherable biotite and more resistant muscovite and potassium feldspars. This explains why it is more equally distributed between the particle size fractions than magnesium.

Extraction with an acid at a higher temperature is used for the estimation of the reserves of more readily available nonexchangeable potassium. It is not known to what extent dissolution in hot acid will characterize the availability of nonexchangeable magnesium. If it would give an idea of the more or less mobilizeable reserves of this nutrient, most of these soils seem to be fairly well provided 
with it. At least, the nonexchangeable magnesium appears to be more readily available than the nonexchangeable calcium and potassium in all the fractions. This is in accordance with the results published in the Rothamsted Report for 1965 (p. 61-62): in six British soils up to 30 per cent of total magnesium in the clay was released when incubated with hydrogen-saturated ion-exchange resins for up to 43 days. About 10 per cent of total potassium was released from the clay fraction in the same way. Also the silt fraction released magnesium faster than potassium relative to the total amounts present.

Between the clay and silt fractions there was a relatively close correlation in respect to their contents of total calcium and total magnesium, and in respect to their contents of nonexchangeable acid-soluble calcium, magnesium and potassium. This is in accordance with the supposition that differences in the mineralogical composition of the clay and silt fractions are more of a quantitative than a qualitative kind. The good correlation between the silt and fine sand fractions in their contents of total calcium, total magnesium, and nonexchangeable acid-soluble parts of magnesium and potassium may perhaps be taken to indicate that the mineralogical composition of the silt and fine sand fractions are not quite different.

There was some indication that the ratio of the amounts of readily exchangeable calcium to those of magnesium and potassium tended to increase with the size of particles from clay to fine sand. This observation may be worth of further research.

\section{S $u m$ m ary}

Samples of three layers of ten mineral soils were separated into the fractions $<2 \mu, 2-20 \mu$, and $20-200 \mu$, without destroying organic matter. The separates were analysed for total calcium, magnesium and potassium, and for the nonexchangeable parts of these nutrients released by acid at $50^{\circ} \mathrm{C}$. Readily exchangeable calcium, magnesium and potassium were also estimated.

The average total content of $\mathrm{Ca}$ was $1.09 \pm 0.13 \%$ in the clay, $1.53 \pm 0.10 \%$ in the silt, and $1.61 \pm 0.10 \%$ in the fine sand fractions analysed. The $\mathrm{Mg}$ content was $2.01 \pm 0.14 \%$ in clay, $1.10 \pm 0.10 \%$ in silt and $0.54 \pm 0.06 \%$ in fine sand, that of $\mathrm{K}$ was $3.02 \pm 0.11 \%$ in clay, $2.75 \pm 0.10 \%$ in silt, and $2.16 \pm 0.13 \%$ in fine sand.

Treatment with acid at $50^{\circ} \mathrm{C}$ released from $100 \mathrm{~g}$ of the clay fraction, on an average, $160 \pm 30 \mathrm{mg}$ nonexchangeable $\mathrm{Ca}, 680 \pm 110 \mathrm{mg} \mathrm{Mg}$, and $400 \pm 70 \mathrm{mg} \mathrm{K}$. From $100 \mathrm{~g}$ of the silt fraction was released $130 \pm 30 \mathrm{mg} \mathrm{Ca}, 350 \pm 70 \mathrm{mg} \mathrm{Mg}$, and $230 \pm 50 \mathrm{mg} \mathrm{K}$. From $100 \mathrm{~g}$ of fine sand, averagely $120 \pm 30 \mathrm{mg} \mathrm{Ca}, 90 \pm 30$ $\mathrm{mg} \mathrm{Mg}$, and $60 \pm 20 \mathrm{mg} \mathrm{K}$ was dissolved. These amounts correspond to about one third of the total magnesium content of the silt and clay fractions, and to about one sixth in the fine sand fraction. The average amounts of calcium and potassium released from the clay fraction corresponded to $13-14$ per cent of the total content in this fraction, to 9 per cent in silt, and in the fine sand material to 7 per cent of total calcium and to about 3 per cent of total potassium.

The relationship between the total calcium contents in the clay and silt fractions is characterized by the total linear correlation coefficient $\mathrm{r}=0.84^{* * *}$, that 
between the magnesium contents with $\mathrm{r}=0.79^{* * *}$, and that between the potassium contents with $\mathrm{r}=0.66^{* * *}$. Between these fractions the correlation in the contents of nonexchangeable acid-soluble calcium was $r=0.81^{* * *}$, of magnesium $\mathrm{r}=0.81^{* * *}$ and of potassium $\mathrm{r}=0.87^{* * * *}$.

Between the silt and fine sand fractions the relationships are characterized by the followirg coefficients: $\mathrm{r}=0.86^{* * *}$ for total calcium, $\mathrm{r}=0.70^{* * *}$ for total magnesium, and $\mathrm{r}=0.40^{*}$ for total potassium; $\mathrm{r}=0.53^{* *}$ for nonexchangeable calcium released by acid, $\mathrm{r}=0.78^{* * *}$ for magnesium, and $\mathrm{r}=0.86^{* * *}$ for potassium.

The clay fraction contained, on the average, about three times as much readily exchangeable calcium, four times as much magnesium, and almost six times as much potassium as the silt fraction. In the clay fraction there was somewhat less than six times as much readily exchangeable calcium, and about fourteen times as much readily exchangeable magnesium and potassium as in the fine sand fraction. On the equivalent basis, the ratio of $\mathrm{Ca}: \mathrm{Mg}$ was about 2 to 1 in the clay fraction, about 3 to 1 in the silt fraction, and about 5 to 1 in the fine sand material. In all fractions the ratio of readily exchangeable magnesium to potassium was 8-10 to 1 .

The results were discussed on the basis of the information about the mineralogical composition of Finnish soils.

\section{REFERENCES}

Brown, I. C. \& Byers, H. G. 1932. The fractionation and hypothetical constitution of certain colloids derived from the great soil groups. U. S. Dept. Agric. Bull. 319.

Hall, A. D. \& Russell, E. J. 1911. Soil surveys and soil analyses. J. Agr. Sci. 4: 182-223.

Hendrick, J. \& OGg, W. G. 1916. Studies of a Scottish drift soil. Part I. The composition of the soil and of the mineral particles which compose it. Ibid. 7: 458-469.

Keränen, T. 1946. Kaliumista Suomen maalajeissa Summary: On potassium in Finnish soils. Acta Agr. Fenn. 63.

Puchner, H. 1907. Uber die Verteilung von Nährstoffen in den verschiedenen feinen Bestandteilen des Bodens. Landw. Versuchsstat. 66: 463-470.

Salminen, A. 1935. On the weathering of rocks and the composition of clays. Agrogeol. Julk. No 40. Soveri, U. 1956. The mineralogical composition of argillaceous sediments of Finland. Ann. Acad. Sci. Fennicae A III. 48.

- _ \& НYурPÄ, J. M. I. 1966. On the mineralogy of fine fractions of some Finnish glacial tills. State Inst. Tech. Res. Finland Publ. 113.

S E L O S T U S:

SAVES-, HIESU- JA HIETAFRAKTIOIDEN KALSIUMIN, MAGNESIUMIN JA KALIUMIN PITOISUUDESTA

Armi Kalla ja Ritva Ryti

Yliopiston maanviljelyskemian laitos, Viikki

Kymmeren maan kolmesta kerroksesta otetuista näytteistä eristettiin savesta, hiesua ja hietaa poistamatta orgaanista ainesta.

Todettiin, että saveksessa oli keskimäärin $1.09 \pm 0.13 \% \mathrm{Ca}, 2.01 \pm 0.14 \% \mathrm{Mg}$ ja $3.02 \pm 0.11 \%$ 
$\mathrm{K}$, hiesussa $1.53 \pm 0.10 \% \mathrm{Ca}, 1.10 \pm 0.10 \% \mathrm{Mg}$ ja $2.75 \pm 0.10 \% \mathrm{~K}$, sekä hiedassa $1.61 \pm 0.10 \%$ $\mathrm{Ca}, 0.54 \pm 0.06 \% \mathrm{Mg}$ ja $2.16 \pm 0.13 \% \mathrm{~K}$.

Käsittely suolahapolla $50^{\circ} \mathrm{C}$ :ssa vapautti vaikeasti vaihtuvaa ja vaihtumatonta kalsiumia savifraktiosta keskimäärin $160 \pm 30 \mathrm{mg} / 100 \mathrm{~g}$, hiesusta $130 \pm 30 \mathrm{mg} / 100 \mathrm{~g}$ ja hiedasta $120 \pm 30 \mathrm{mg} / 100 \mathrm{~g}$. Vastaavat magnesiumin määrät olivat saveksesta $680 \pm 110 \mathrm{mg} / 100 \mathrm{~g}$, hiesusta $350 \pm 70 \mathrm{mg} / 100 \mathrm{~g}$ ja hiedasta $90 \pm 30 \mathrm{mg} / 100 \mathrm{~g}$, ja vastaavat kaliumin määrät saveksesta $400 \pm 70 \mathrm{mg} / 100 \mathrm{~g}$, hiesusta $230 \pm 50 \mathrm{mg} / 100 \mathrm{~g}$ ja hiedasta $60 \pm 20 \mathrm{mg} / 100 \mathrm{~g}$.

Savifraktiossa oli helposti vaihtuvaa kalsiumia keskimäärin kolme kertaa niin paljon kuin hiesussa ja lähes kuusi kertaa niin paljon kuin hiedassa. Saveksessa oli neljä kertaa niin paljon magnesiumia ja miltei kuusi kertaa niin paljon kaliumia kuin hiesussa sekä molempia noin neljätoista kertaa niin paljon kuin hiedassa. Saveksessa Ca: Mg oli keskimäärin noin 2, hiesussa noin 3 ja hiedassa noin 5 . Kaikissa fraktioissa Mg:K oli 8-10.

Saveksen ja hiesun välillä todettiin seuraavat vuorosuhteet: $\mathrm{r}=0.84^{* * *}$ kalsiumin kokonaispitoisuuksien, $\mathrm{r}=0.79^{* * *}$ magnesiumin kokonaispitoisuuksien ja $\mathrm{r}=0.66^{* * *}$ kaliumin kokonaispitoisuuksien välillä. Vastaavat kokonaiskorrelaatiokertoimet happoonliukenevien vaihtumattomien määrien välillä olivat $\mathrm{r}=0.81^{* * *}$ kalsiumin, $\mathrm{r}=0.81^{* * *}$ magnesiumin ja $\mathrm{r}=0.87^{* * *}$ kaliumin kohdalla.

Kalsiumin kokonaispitoisuuksien riippuvuutta hiesu- ja hietafraktioissa luonnehti korrelaatiokerroin $\mathrm{r}=0.86^{* * *}$, magnesiumin $\mathrm{r}=0.70^{* * *}$ ja kaliumin $\mathrm{r}=0.40^{*}$. Hiesusta ja hiedasta happoon uuttuvan vaihtumattoman kalsiumin määrien välinen vuorosuhde oli $\mathrm{r}=0.58^{* * *}$, magnesiumin $\mathrm{r}=$ $0.78^{* * *}$ ja kaliumin $\mathrm{r}=0.86^{* * *}$.

Tuloksia tarkasteltiin niiden tietojen perusteella, joita on käytettävissä maittemme kivennäiskoostumuksesta. 